ISSN: 2349-2031

(C) 2018, THEIJSSHI

Research Article

\title{
Sensitive Language Behaviour as a Trigger of the Conflict within Interethnic Family in Tapal Kuda Regions
}

\author{
Akhmad Haryono ${ }^{1}$ and Bambang Wibisono ${ }^{2}$
}

Faculty of Culture Science, University of Jember

Jl. Kalimantan, 37 Kampus Tegalboto Jember, Jawa Timur, Indonesia

\begin{abstract}
Interethnic marriage has has long been happening in such Tapal Kuda regions as Jember, Bondowoso, Situbondo, and Lumajang of East Java province. However, this marriage tends to be in communication failure. If it is not managed properly, it can lead to the conflict that can bring about divorce. Divorce is not only triggered by the economical factors, but also by the failure of communication. For this fact, this research aims at exploring and describing linguistic knowledge, application of interaction skill, cultural knowledge, and factors that can lead to communication failure. To achieve the objectives of the study, it uses a qualitative approach with a focus on ethnographic study of communication. The data were obtained through participant observation and non-participation, as well as interviews with recording technique. The data obtained is transcribed to written data, then analyzed by using the ethnography of communication (speaking grid) and discourse analysis with pragmatic concept. This study yields the findings that the sensitive matters that can trigger conflict constitute lack of linguistic knowledge of local languages owned by each interethnic marriage and lack of interethnic cultural understanding that impact on violations of the principles of politeness and cooperation principles in different cultures thus triggering conflict both within the family and inter-families. Finally, this study concludes that the lack of linguistic knowledge possessed by married couples, especially the understanding of the verbal and nonverbal elements in communicating can lead to communication failure and trigger the occurrence of conflict that impact on the emergence of divorce
\end{abstract}

Key words: tapal kuda, ethnic, pendalungan, communication, politeness principle

\section{INTRODUCTION}

The Javanese, Madurese, Osing, Chinese, and other ethnic groups have long lived and settled in such Tapal Kuda (Horseshoe) regions as Jember, Bondowoso, Situbondo, and Lumajang, East Java. Many of them has got married interethnically. As a result, acculturation is unavoidable that it produces a hybrid culture which is known as the pendalungan culture (Madurese: pandhelungan; Javanese: medhalungan) (Wibisono, 2016). Interethnic marriage has a positive aspect as one of the efforts to strengthen the unity within Indonesia.

However the marriage tends to have the conflict within the family, which is frequently ended with dissolution of the marriage. This can be verified by the high rate of marriage dissolution in Tapal Kuda regions, which reaches the highest rank in East Java.

Research by Wibisono and Haryono (2014) found out that the conflict within the family that ends with dissolution of the marriage is not only caused by economical factor, but also by the failure of communication. The communication failure is assumed to be caused by differences in language and cultural understanding that each communicant possesses when they communicate. Often the very trivial problem, which originally occurs only between husband and wife, can develop into a serious problem, involving the whole family of the husband and wife, leading to the emergence of divorce.

This research article discusses the important verbal and nonverbal elements that need to be considered in the communicating practice. If it is not addressed properly, it can trigger the conflict within the family. This exposure is expected to be used as anticipation and communication failure solution of the conflict that often occurs in interethnic marriage families at multi-ethnic communities. Theoretically the research article is written to enrich the scientific repertoire in the fields of communication ethnography, pragmatics, and cross cultural communication. Furthermore, it can be used as additional reference for the religious marriage officer in charge (Ministry of Religious Affairs of the Republic of Indonesia, in this case KUA/Religious Affairs Office) for the their duty performance.

According to Brown (1999) and Levinson (1985) the lack of linguistic knowledge, interaction skills, and intercultural understanding (verbal and nonverbal) can interfere with the fluent communication. The communication failure can be caused by low communicative competence and violation of communication principles and strategies, for example, the low knowledge of politeness principle and cooperative principle by speakers and partners. According to Griece (1975: 47), Yule (1996: 36-37), Nadar (2008: 24-25), and Haryono (2018) the Principle of Cooperation is divided into 4 maxims. The first is the quality principle which suggests making the right conversation. The second is the principle of quantity which suggests making the conversational contribution as informative as possible for the conversation, for example, not to make the conversation less informative than necessary. Furthermore, the third is the principle of relationship or 


\section{Akhmad Haryono et al / Sensitive Language Behaviour As A Trigger Of The Conflict Within Interethnic Family In Tapal \\ Kuda Regions}

relevance (relation or relevance) which suggests making your conversation relevant. The fourth is the principle of manner that suggests speaking clearly: (a) avoid vagueness, and (b) avoid coercion.

The violations of the linguistic politeness principle, for example violations of: (1) interaction norms, (2) interpretation norms, and (3) turn taking norms in communication which are parts of the interaction skill and culture knowledge aspect can also be the cause of communication failure. Thus, the cooperative principle in a conversation is a guide that needs to be considered and obeyed by the speakers and speech participants in communication events, so that the communication takes place smoothly and effectively, and no communication failure. In order to do so, in communicating it is advisable to make conversation contribution in such a way as desired, in accordance with the development of the context or situation of the conversation and in accordance with the intent or direction agreed in the conversation. We need PK to more easily explain the relationship between meaning and power; such an explanation is sufficient, especially to solve the problems that arise in truth-based approximation of semantics. The cooperative principle is needed to more easily explain the relationship between meaning and power; such an explanation is sufficient, especially to solve the problems that arise in semantics with truth-based approach.

According to Hymes (1982b), the communicative competence involves knowledge not only about the language code, but also about what to say to whom, how to say, when can be said, and how the right situation to say it. The communicative competence has a relationship with the social and cultural knowledge that the speaker has to help them use and interpret linguistic forms. This competence involves both verbal and nonverbal explanations.

Language is not only about grammar, but also about the suitability of its usage in certain contexts. Learning the language is not only learning the grammar, but also about when to speak and when not to speak, what to speak, with whom, when, where, then how to speak.

In addition, the competence principle is an inseparable part of attitudes, values, and motivations relating to language, its sides and usage, and can not be separated by competence to determine attitudes toward language interrelation with codes and other symbols of communicative act (Hymes, 1982 b: 277-278).

The discussion of communicative and linguistic competence (grammatical) usually ranges from two points: (1) the need to include grammatical descriptions with appropriate conditions; (2) the balance between grammatical (or linguistic) codes with other aspects such as body movement, eye gaze, and so on (Hymes, 1982 b).

The communicative competence includes both knowledge and expectation about who can or can not speak in a certain setting, when to say it and when to be silent, who to talk to, how one speaks to people of different roles. In addition, it also concerns the ability and knowledge of which nonverbal behaviors are appropriate for the various contexts, what routines are going on for the turn shift in the conversation, how to offer help and cooperation, how to ask and inform, how to enforce discipline and so on (Ibrahim, 1994)

In addition, the communicative competence refers to the knowledge and skills in the use and interpretation of contextually appropriate language in a society. It refers to the knowledge and communicative skills shared by a particular group (like other aspects of a culture), although this varies greatly in group members involving different individuals. The nature of individual competence reflects the nature of the language (Saville-Troike, 2003)

The cross-cultural differences can produce conflicts or lead to communication failure. For example, issues such as sound levels may differ cross-culturally, and speakers' intentions can be misunderstood because of different interpretation expectations. Therefore, communicative competence must be added in the concept of cultural competence, or the overall knowledge and skills brought in a situation. This view is consistent with the semiotic approach that defines culture as meaning, and sees all ethnographers associated with symbols (check Geertz, 1973, Douglas 2000). Thus it can be said that the cultural system is a symbolic pattern, and language is one of the symbol systems in this framework. The interpretation of linguistic meaning requires knowledge of the meaning in which the linguistic behavior takes place.

The following is a summary of the range of knowledge that speakers need to have in order to communicate appropriately. From an ethnographer's perspective, it shows the range of linguistic, interactional and cultural phenomena that should be given attention in an adequate description and explanation of communication.

The first is linguistic knowledge which includes: (a) verbal elements, (b) nonverbal elements, (c) patterns of elements in a particular speech event, (d) possible range of variants (in all elements and organizing the elements), and (e) the meaning of variants in a particular situation.

The second is the interaction skill which includes: (a) perception of important features in communicative situations, (b) selection and interpretation of appropriate forms for particular situations, roles and relationships (rules for speech users), (c) the norms of interaction and interpretation, and (d) communication strategy to deliver intention.

The third is cultural knowledge which includes knowledge of: social structure, values and attitudes, cognitive maps or structures, and enculturation processes, including the transmission of knowledge and skill (Saville-Troike, 2003).

The communicative competence refers to the knowledge and communicative skills shared by particular groups, although this varies in members individually. In essence, such knowledge includes both verbal and nonverbal knowledge.

\section{RESEARCH METHOD}

The approach used in this study is a qualitative approach with 


\section{Akhmad Haryono et al / Sensitive Language Behaviour As A Trigger Of The Conflict Within Interethnic Family In Tapal \\ Kuda Regions}

a focus of communication and pragmatic ethnography studies. The study of ethnography of communication according to Kuswarno (2008) a study that can describe, explain, and build relationships from the categories of data found. This is in line with the objectives of ethnography communication, that is, to analyze, describe, and explain the communication behavior of a social group or community. The pragmatic is the study of the meaning and purpose desired by the speakers and accepted (interpreted) by the speakers (participants of speech, opponent of speech, speech partner) by paying attention to the relationship with speech situations.

The method used to enter the research site was a non-formal technique. This has been done to ensure the authenticity of data obtained from research subjects as well as from direct observations in the research site. To support non formal techniques as mentioned above, the role of researchers in this research was classified. The researchers concealed their identity as researchers and the researchers acted as the intelligent to ensure the validity and authenticity of the data.

The location of this research is in Tapal Kuda regions (Jember, Bondowoso, Situbondo, and Lumajang), East Java. The data were obtained by observation and interviews to intercultural marriages directly, either to those who managed to perpetuate marriage or those who failed to maintain the integrity of the household.

The interviews were conducted to obtain information about communication behavior and speech acts that were exhibited by interethnic marital community in communicating. The interview activities were conducted by semi-directional, by using a list of questions that have been prepared by the researcher, but it has been memorized by researchers. The use of semi-directed interviews aims to make the study seem less formal, so the subject of research is not shy to give the widest explanation to the researcher, without having to deviate from the main purpose of research.

The recording activity was executed by using a mini tape recorder or a cell-phone stored in a pocket. This activity was conducted to record the communication process and interview as a complement to overcome the limitations of the researcher in recording directly the communication process in participant observation and interview. It was carried out to record data obtained from the field directly, in the sense that all data and information obtained in the field were recorded carefully on the same day. This activity was conducted with the intent to avoid the possibility of forgetting or overlapping data and overcome the loss of information obtained, either through participant observation or from research informants.

The data collected were phonologically transcribed into the written data. That is, the words in the data were transcribed as they were according to the utterances expressed by the research subject and the spelling rules applied in the language, in order that the phonological characteristics of the language presented in the oral data could be expressed in the written data that has been transcribed. The data were analyzed descriptively-analytically according to the problem that was

attempted to be answered in the research, that is, describing important verbal and nonverbal elements that need to be considered in interethnic communication using SPEAKING grid analysis and discourse analysis with the help of pragmatic concept.

\section{RESULTS AND DISCUSSIONS}

The following are the findings of verbal and nonverbal elements that are often the triggers of conflict within the families of interethnic marriages in Tapal Kuda regions. Included is the range of linguistic and pragmatic knowledge that interethnic marriage actors have in Tapal Kuda as speakers and listeners (participants) in communicating.

\section{Verbal Element}

From the research conducted, it is known that linguistic knowledge in the form of mastery of verbal elements, from interethnic marriage actors in Tapal Kuda regions can speak Indonesian. It is not a trigger element of misunderstanding in communicating. Verbal element that often becomes the trigger of misunderstanding, which in turn becomes the trigger of the conflict in the family, is the use of verbal elements of local languages owned by each interethnic marriage actors. For example, the Javanese wives use Javanese when communicating with the Madurese husbands, or vice versa.

Due to the lack of understanding of the meaning of verbal elements of regional languages used by each interethnic marriage, not infrequently then there is a misunderstanding that triggers the occurrence of conflict. This is as experienced by the family of one of the interethnic marriage actors encountered by the researcher.

There was a husband from Madurese ethnic, in Bondowoso, whose wife was Javanese ethnic, from Wuluhan (South Jember). They lived in Jember. At that time they both kept people harvesting rice crops in the wife's rice paddy. Seeing the husband (AG) who did not feel at home in the rice field because he was a chicken trader, the wife (Y) told him to go home first, with the command using the following Java language.

\section{Y: Wis, sampeyan muliya dhisik!}

(Please go home first!)

AG: without saying any words he went straight home.

In the speech situation in the morning rather noon mentioned in the above data, the wife's speech to the husband aims to have the husband rest at the wife's parent's home because in the rice field he does not do anything and the wife dares to go home alone, and will go home later because the rice harvest has not been completed yet. However, due to his misunderstanding of the wife's order, the husband went straight home to his parents. When the wife came home, the husband was not in the house of her parents, then the wife calls him to ask where he is. In fact her husband is in his home in Bondwoso. After that there is a conflict between them. 


\section{Akhmad Haryono et al / Sensitive Language Behaviour As A Trigger Of The Conflict Within Interethnic Family In Tapal \\ Kuda Regions}

The misunderstanding here is triggered by the husband's lack of understanding of the Javanese command, he thinks that he is asked to return home for not doing anything. The spouse also violates the principle of cooperation to the maxim of quantity, which suggests making a conversation as informative as possible in line with the necessity in the conversation. In the conversation the wife gives incomplete order with her intention, so the husband felt offended to be sent home. The tension is seen from the non verbal attitude of the husband who does not say any words to his wife and immediately leave her. From the aspect of interaction and interpretation norms, the wife has violated the principles of politeness because she orders the command sentence not with the interrogstive sentence such as "Opo sampèyan èna'è mulih dhisik yo, Supoyo iso istirahat nang omah." (Is it okay for you to go home first, in order that you can get a rest at home). The speech in interrogastive form has the value and principle of politeness as well as the complete purpose of the speech, so that it does not violate the politeness principle and the cooperation principle of the quantity maxim.

The tone as part of speech component also often triggers misunderstanding between speakers and speech participants. It can be seen from the following speech event in the conversation between the husband named Strisno (S) and the wife Iis (I).
$\mathrm{S}:$ Dik $k^{\uparrow}$ buka pintunya ${ }^{\uparrow !}$
(Open the door ${ }^{\uparrow}$ !)
I: $y a^{\uparrow}, S i ' r a^{\uparrow}$, se' nutukno lempit-lempit.
(Yes ${ }^{\uparrow}$, a moment, still finishing folding clothes)
S: Abech ${ }^{\uparrow}$ kok da' cepetan ${ }^{\uparrow}$ !
$\left(\mathrm{Ah}^{\uparrow} \ldots\right.$ be quick ${ }^{\uparrow}$ !)
I: Siah ${ }^{\uparrow}$, ma’ dim makodim.
(Yach ${ }^{\uparrow}$... kok sok gawat)

The speech situation occurs during the day when the husband comes home from work, while the wife is tidying up the clothes. The husband is from the coastal area where he is accustomed to high-velocity pressures $(\uparrow)$ so that the wife who from the morning finishes work at home feels offended by the husband's high-pressure voice. In the coastal area where the husband comes from, the tone of high-pressure voice in communicating is very common. Unfortunately, the wife replies in high voice too, and even taunts him with the words 'dim makodim', that is, the phrase in Tapal Kuda regsions is commonly used to mock the snooty person. The high tone that has built interaction norms includes the politeness principle that prevails in the Tapal Kuda regions. A wife should not have higher voice than her husband, however, according to the view of the Muslim religious leaders, the husbands must also behave well to the wife including in communication not using high tone of voice.

The misunderstanding that leads to the communication failure of is caused by the cultural misunderstanding indicated in the verbal language of the sound pressure. Therefore, the intercultural and interethnic marriage actors need to understand well the verbal and cultural elements of the local language of their partner's origin in order to avoid the conflict as the result of communication failure. Those who are Javanese people, for example, master the Madurese language, and those who are Madurese master the Javanese language, if they are the inter-ethnic couples from Java-Madura.

\section{Non verbal element}

Several important nonverbal elements that can be one of the triggers of interethnic marital family conflict in the Tapal Kuda regions are discussed in this section. In this relation, it is found that there are interethnic marriages who fail to maintain the integrity of their families. One of the triggers is that the wife does not like to the husband's nonverbal behavior when they communicate. One of the interethnic marriage couples, who experienced this family conflict, is a couple of Suyati and Krisman Sihombing. In 2017 Mbak Yatik (Suyati) was 45 years old. She lives at jalan Kalimantan X Number 247 Jember. Last time she had ever got married to Krisman Sihombing, but they got divorced after a year of their marriage with no children. This divorce was due to Krisman Sihombing's impolite attitude when they were communicating. After being divorced, Suyati then got married to Mr. Marwoto and they got two children. Below is an excerpt of Suyati's statement in the interview with the researcher $(\mathrm{R})$. In this interview made on Monday, January 02, 2017, Suyati is commonly called Mbak Yati (Y).

\section{R: Dimin Mbak Yatik toman nikah bân Mas Krisman ya} Mbak? Anapa ma' apèsa?

(One time, Mbak Yatik had ever got married to Mas Krisman ya Mbak? Why did you get divorced?)

Y: Iyâ, apa Krisman rèya. Orèngnga ta' sopan. Ta' cocok engko'. Ta' kowat. Engko' pas minta èpesa.

(Yes, What is Krisman?. He is impolite?. He is not fit to me. I cannot stand it anymore. I asked him for divorce.)

$\mathrm{R}$ : Tak sopan bârema?

(How is he impolite?)

Y: Iyâ, mon abânta bân sengkok tanangnga akad bingkeng bân ding-noding. Tak sopan lah. Poko'en ta' sopan. Bân matana mandelik... thot-malothot. Mon abântha tag-nyentag. Tako' engko'. Rèng sè ngiding bân sè tao bhâi sampè tako'.

(Yes, when speaking to me, one arm is akimbo and the other arm is pointing. He is impolite. The main thing he is impolite. And, his eye goggles. The people who hear and see him become scared).

From the interview it is recognized that the family conflict occurs because when communicating with each other, the speech participants do not care the nonverbal aspects related to the communication politeness. The politeness here is the attitude when speaking. For example, such akimbo arm, pointing arm, and bulging eyes are the attitudes that can make the speech partners become offended because they feel disrespected, and even scared. Such attitudes are non verbal aspects or non verbal elements that most people at Tapal Kuda regions dislike, mainly the women. If these aspects are not paid attention, they can trigger the conflict. As a result, the 
people violate the norms of interaction in communicating if they do not care such non verbal aspects.

Another nonverbal element that became one of the triggers of the conflict of interethnic marriage family in Tapal Kuda is the violation of the act sequence norm in communicating. In this case, it is found that there are interethnic marriage actors that fail to strengthen their families because one of the triggers is that the wives do not like the nonverbal behaviors of the husband when they communicate.

The following is the recognition of one of the research subjects (Mbak Surti, commonly called Mbak Titik) to researchers. Mbak Titik is now 47 years old and lives in Lumajang. Mbak Titik once married to Sudarisman, but divorced. She then got married again Cak No (Cak Suwarno, 50 years old with the same Javanese ethnic as Mbak Titik. Her marriage to Sudarisman lasted only 1 year. They divorced because when communicating, Sudarisman often showed a disrespectful attitude. Her marriage to Sudarisman had no children, but her marriage to Mas Suwarno had two children. The recognition was presented to the researcher during the interview conducted on Monday, January 02, 2017. Mbak Titik (T) expressed her statements to the researcher (R) as follows.

\section{R: Riin Mbak Titik nate sima kalian Mas Sudarisman nggeh Mbak? Nopo'o kok pegatan?}

(One time, Mbak Yatik had ever got married to Mas Sudarisman ya Mbak? Why did you get divorced?)

T:nggeh Mas, Opo. Darisman kui. Wongè moboten purun ngalah. Tiangè kathah... omongè. Ngmong tok, mboten purun ngrungu'no omonganè wong.Tiange moboten purun ngru'ke tiang istri. Le' kulo ngomong piamba'e nggeh ngomèl. Mboten remen kulo, mboten kiat kulo, akhire nyuwun pegatan.

(Yes, Mas. What's Sudarisman. He doesn't want to give up. He talks a lot, always keeps talking. He doesn't want to listen and always keeps talking. He doesn't want to listen to woman's speaking. When I speak, he speaks, too. He doesn't like me. I can't stand it any more. Finally I ask him for divorce).

From the statements it is recognized that one of the causes of Mbak Titik's divorced with Mas Darisman is because in communicating Mas Darisman doesn't want to budge, doesn't want to listen to what was said by his wife. Thouh his wife has not finished speaking, Mas Darisman has interrupted his wife's talk. In fact, he always keeps his speaking. Because Mbak Titik does not like her husband's attitude in suchway, she feels not fit to him. As a result, she asks him for divorce. For this fact, the attitude of willing to succumb, listen to the speech of the opponent when speaking is important nonverbal element in communication, so that the relationship between husband and wife remain harmonious. This case is also a violation of "act sequence" speech component that also affects the other components of speech that the husband is not concerned with the wife as the speech participant that should be treated well, not paying attention to how the intent and purpose of speech can be well received by the speech opponent, so the form of the message also becomes unclear that it does not reach the speech opponent. This non-verbal element has also violated the interaction norms of disrespecting the wife in speaking. If the violation of the speech component is not paid attention, it can lead to the family conflict, and cause the divorce.

Furthermore, another nonverbal element that becomes one of the triggers of inter-family marital conflict in Tapal Kuda regions is the violation of socio-cultural societal norms. In this relation, it is recognized that there are interethnic marriage actors who fail to retain their families because one of the trigger is that the husband does not like the the wife's nonverbal behavior. It is like that experienced by the family of Mas Supono. The following is the recognitiont of Supono (S) that the researcher $(\mathrm{R})$ calls him mas Pono. He is now 56 years old, living in Situbondo. Once married to Mbak Sri, but divorced, then married again with Mbk Santi, a woman of Madurese ethnic. His marriage with Mbak Sri lasted only 2 years. The divorce happens because Mas Pono does not like one of Mbak Sri's attitudes. The Researcher has ever lived at the house of Mas Pono's parents when implementing Community Sevice program. The Interview was conducted on Sunday, February 27, 2017 as in the following.

\section{(R): Dimin Mas Pono perna nika sareng Mbk Sri? Anapa} ma'apesa?

(One time Mas Pono had ever married with Mbak Sri? Why did you get divorced?)

S: Iyâ, napa, Mbk Sri nèka. Orèngnga korang sopan. Tak cocok ghulâ. Mon abhânta bân orèng towa ta' sopan. Tak nundu', soarana tèngghi atembhâng orèng seppo, mon asalaman ta' èciom. Engko' todhus ka msyarakat bân taretan è dinna, è beccè' la ta' bisa, akhèra ddaddi tokarran, jhiâ sè dâddi lantaran apèsa.

(Yes. What's Mbak Sri. She is impolite. She doesn't fit me. When speaking to old person, she is impolite, doesn't want to bow, her vocie is higher than the paretns', when shaking hand with them she never kisses their hands. I become shy to society, brother and sister here. She has been asked to improve her attitude, but she can't. Finally the conflict happens. That is the cause of my being divorced).

From the statements above, it is recognized that one of the causes of the divorce of Mas Pono with Mbk Sri is due to the behavior of Mbak Sri who does not want to obey the sociocultural norms of society in the regions of Tapak Kuda. Mbk Sri violates the socio-cultural norms in force in the Madurese community. One is that when shaking hand with parents, she does not kiss their hands. She does not bow her body and head when communicating with parents. Because the husband feels shy and dislikes such his wife's attitude, he feels usuited to her, cannot bear of feeling shy, and then he divorces his wife because he feels unable to improve his wife's behavior. For this fact, the spouse must be able to adjust to the socioculture of each partner. The couples have to pay attention to social norms that exist in society which are important nonverbal elements that need to be known, understood, and obeyed. If 
Akhmad Haryono et al / Sensitive Language Behaviour As A Trigger Of The Conflict Within Interethnic Family In Tapal Kuda Regions

they do not obey such norms, their relationship (as the husband and the wife) can become in disharmnony. If it happens repeatedly, it can trigger the conflict in the family, and becomes one of the causes of divorce.

\section{CONCLUSION}

In Tapal Kuda regions, there are a number of interethnic marriages that fail to perpetuate the family integrity. The failure is not only caused by economic factors, but also the lack of linguistic knowledge own by interethnic couples (husband and wife), especially the understanding of the verbal and nonverbal elements used in communicating. Due to the lack of understanding of the meaning of verbal elements of regional languages used by each interethnic marriage actors, the misunderstanding and communication failure that trigger the occurrence of conflict frequently happen. In addition, nonverbal elements that trigger family conflicts, because they are not liked, are talking with hands on the hips, pointing fingers, bulging eyes, and speaking at a very loud volume. These are considered as the violation of the politeness principle. Other nonverbal elements that often trigger the occurrence of conflict in the family are the attitudes of not willing to budge, do not want to listen to the partner's talk, and the attitude of interrupting the interlocutor, as well as violating socio-cultural norms. Thus, in communicating there are three important things, namely linguistic knowledge, interaction skills, and cultural knowledge of the language used. If the three things are not fulfilled, then they can be the trigger of communication failure that affects the occurrence of conflict in family that can finally lead to the occurrence of divorce.

\section{ACKNOWLEDGEMENT}

Thank you very much to Rector of University of Jember, Dean of Faculty of Public Health, University of Jember, and DRPM Ministry of Research Technology and Higher Education Indonesia for the support and assistance of this research realization.

\section{REFFERENCES}

[1] Brown. P. and Levinson, S.1999. 'Universal in language usage: politeness phenomene'. In E. Goody(ed.) Question and politeness: Strategies in social interaction. Cambridge: Cambridge University Press.

[2] Douglas, H. Brown. 2000. Principles of Language Learning and Teaching. New York: Longman.

[3] Geertz, C. 1973. The Religion of Java. Chicago: Chicago University Press.

[4] Grice, H.P. 1975. 'Logic and Conversation', dalam Cole dan Morgen. Radical Pragmatics. New York: Akademic Press, pp. 41-58.

[5] Haryono, A. 2018. "Communication Patterns Among Kiais Of Nahdlatul Ulama In The Madurese Ethnic Group" dalam Indonesian Journal of Applied Linguistic (IJAL) Vol 7, No 3, Januari 2018, p.714-726.
[6] Haryono, A. 2005. Tradisi Perkawinan Usia Dini: Studi Kasus Etnik Madura di Jember. Universitas Jember: Laporan Penelitian.

[7] Hymes. D. 1982b. Postface.in Hymes. 1982a. Vers la competence de communicatin. Trans. by F. Mugler. Paris: Hatir Credif.

[8] Ibrahim, A. S.1994. Panduan Penelitian Etnografi Komunikasi. Surabaya: Usaha Nasional.

[9] Kuswarno, E. 2008. Etnografi Komunikasi: Suatu Pengantar dan Contoh Penelitiannya. Bandung: Widya Padjadjaran.

[10]Leech, G. 1993. Prinsip-prinsip Pragmatik. Terjem. dari The Principle of Pragmatics. Diterjemahkan oleh MDD Oka. Jakarta:UI Press.

[11]Levinson, Stephen C. 1985. Pragmatics. Great Britain: Cambridge University Press.

[12] Nadar, F.X. 2008. Pragmatik dan Penelitian Pragmatik. Yogyakarta: Graha Ilmu.

[13] Saville-Troike, M.. 2003. TheEthnographi of Communication: an Introduction. New York: Basil Blackwell Inc.

[14] Wibisono, B. 1999. Penggunaan Gaya Retoris Tidak Langsung pada Masyarakat Pendalungan Madura di Jember. Laporan Penelitian:Universitas Jember.

[15] Wibisono, B. 2005. Perilaku Berbahasa Warga Kelompok Etnik Madura di Jember dalam Obrolan dengan Mitra Tutur Sesama dan Lain Etnik. Disertasi: Universitas Negeri Malang.

[16] Wibisono, B. Haryono, A. 2016. Wacana Perkawinan di Tapal Kuda. Jember: Penerbit Tapal Kuda.

[17] Yule, George and Gillian Brown. 1996. Discourse Analysis. Cambridge: Cambridge University Press.

[18] Yule, George. 1998. Pragmatics. Hongkong: Oxford University Press. 